\title{
PUBLIC CONTROL OF PUBLIC AUTHORITIES: SIGNIFICANCE FOR UKRAINE
}

\section{Holubiak N. R.}

\section{INTRODUCTION}

The degree of development of civic society and the formation of good governance are strong indicators of democratic development of the country and approach to the stage of consolidated democracy according to the assessment of the project "Nations-in-transit" by "Freedom House". During the transformation period, many social and political issues of the country remain unchanged, such as the form of relations of civic society with public authorities; how open are the public authorities towards cooperation with the public; what is the level of involvement of citizens into political process; how important is the level of public trust in the state institutions.

History of state-building in Ukraine shows the obvious improvement in the development of civil liberties and civic activity of the population which appears particularly "acute" on the background of public protests, so-called "maidans" and becomes a reference point for future reforms. However, the next step to secure the effective change is the activation of mechanisms of public control in order to ensure real public involvement in the political process and political decisions. In other words, the phenomenon of control directly correlates with openness and transparency of policy, political trust and responsibility, level of political participation and political awareness of citizens.

Thus, the nature of "public control" is a part of civic society and the highest form of civic activity, as evidenced by the importance of the implementation of public control and the effectiveness of public control tools. Let us try answering the following questions: To what extent are the mechanisms of public control regulated in Ukraine? Who should carry out the public control? How significant are the results of public control for the political process? How do the problematic aspects and progressive changes in the controlling influence on public authorities correlate?

The European experience shows that this form of citizen participation in public administration can be successful and effective under the following next conditions: the need for public control as a form of public administration that provides feedback and external evaluation of decisions made; awareness of citizens, public organizations and territorial communities of their responsibility for the state; the existence of a developed legal framework that requires local 
governments to involve members of the public in the formulation and implementation of public policy; legislative regulation of the procedure for using public control mechanisms; providing professional training and professional development of public experts ${ }^{1}$. Therefore, there is an interdependence of good governance, social responsibility and civic position, as the lack of proper feedback leads to negative consequences and stagnation in the political system.

\section{Theoretical and conceptual understanding of "Public control"}

The concept of "control" is an interdisciplinary subject of study of social and human sciences (philosophy, sociology, law, management, political science). This issue originates in the studies of the classics of sociological thought as one of the main elements of the conceptual theoretical sociology. Social control serves as a generic concept for different varieties of control in society. The term "social control" was introduced into scientific circulation by French sociologist and psychologist G. Tarde to describe means of return to normal behavior, complied with the rules of society. In sociological interpretation, control is seen as a mechanism of self-regulation of the system that ensures the stable interaction, contributes to solving conflicts and prevents deviant acts ${ }^{2}$.

Control as part of the social system performs a regulatory function. Based on the nature of the interdependence of people and the need to act together, society shapes certain social roles and patterns of behavior. Consideration of a certain level of social communication actualized the reference to methods of symbolic interactionism. The order of life is the product of everyday interaction of people, including that on the political level. Interest in the procedural aspects justifies the use of the term "control" as one of the techniques for regulation of social relations. For example, American sociologist W. I. Thomas considers technique of group control as a social necessity, i.e. opposes it to the crisis of voluntary act through attribution of unwanted and the appearance of desired effects ${ }^{3}$. T. Shibutani assures of the importance of the study of social control, because human behavior is organized in response to the expectations that are attributed to others. It means that from the standpoint of

1 Середа Т. Стратегічні орієнтири взаємодії органів державного управління 3 громадськістю у процесі реалізації конституційно-правової реформи / Т. М. Середа. Теорія та практика державного управління. 2018. Вип. 2. С. 81.

${ }^{2}$ Корж К. М. Концептуалізація соціального контролю як технологічного засобу стримування соціальних відхилень соціологічних теоріях кінця XIX - початку XX століття / К. М. Корж. Актуальні проблеми соиіології, психології, педагогіки. 2011. Вип. 13. С. 32-41.

Політична думка XX - початку XXI століть: методологічний та доктринальний підходи: у 2-х т./ за заг. ред. Н.М. Хоми. Львів: Новий Світ-2000, 2016. Т. 1. С. 66. 
interactionism, result of the interaction consists not only in establishing aims or behavior under the influence of external factors, but also in a certain degree of consensus, sequence of mutual acceptance of roles ${ }^{4}$.

In the context of law, control is understood as a mechanism to maintain regulatory order; system of sanctions against violators; one of the foundations of the constitutional system; type of social control; part of the institute of democracy; activities of citizens while solving the national issues and so on. In particular, control is functionally performed on the brink of the concepts "act - norm" in form of identifying and bringing acts into compliance with norms on the one hand, and norms into compliance with acts on the other hand.

In political science, a subject of public control is treated as a derivative concept from the social contract theory, technology of feedback, tool of interaction between civic society and public authorities, communication mechanism, as the highest form of political participation.

In order to analyze the relations between civic society and state, let us turn to the paradigm of constructivism, which deals with public policy as a communication space for public activity and construction of political discourse. According to constructivists, changes in the principles of operation of public institutions increase the mobilization capacity of social communities. It means that emphasis on the mode of communication between public authorities and the public not only reflects the level of relations, but plays an important role in its changing and openness 5 .

In particular, Karl Popper regards public control as one of the main features of democratic political regime. In his book "The Open Society and its Enemies", the researcher wrote: "By democracy I do not mean something as vague as "the rule of the people" or "the rule of the majority", but a set of institutions (among them especially general elections, i.e., the right of the people to dismiss their government) which permit public control of the rulers and their dismissal by the ruled, and which make it possible for the ruled to obtain reforms without using violence, even against the will of the rulers"6.

Theoretician of communicative process J. Habermas pays particular attention to the creation of a large number of "public spheres", which allow citizens of the XXI century using open communication in public institutions to control state power at various levels and vast territory which would guarantee their civic rights. "Development of all forms of influence on government

${ }^{4}$ Політична думка XX - початку XXI століть: методологічний та доктринальний підходи: у 2-х т. / за заг. ред. Н.М. Хоми. Львів: Новий Світ- 2000, 2016. Т. 1. С. 73.

${ }_{5}^{5}$ Поцелуйко А. О. Образ держави в соціальному конструктивізмі та структурному функціоналізмі / А. О. Поцелуйко. Грані. 2015. № 7. С. 36.

${ }^{6}$ Поппер К. Відкрите суспільство та його вороги / пер. 3 анг. О. Коваленко: в 2 т. К. : Основи, 1994. Т. 1. С. 179. 
requires constant self-criticism and self-control, since democracy will carry out all its functions accordingly only under conditions of constant "public censor"

A strong civic society, and not the state is the guarantor of the formation and development of democratic institutions. According to L. Diamond, the first and primary function of civic society is to provide a basis for limiting state power, and thus for society controlling the state. In his opinion, an important aspect of quality of democracy is active and pluralistic civic society, in which citizens take seriously not only their responsibility to express their interests and values, but also the control of public authorities and the monitoring of their activities. This is a function of independent media, NGOs, think tanks and others ${ }^{8}$.

F. Fukuyama argues that people tend to pursue their own interest while being part of the public authorities, but the reason for this is the weakness of institutions for counteraction, prevention and control. The democratization process involves several necessary conditions, namely a high level of education in society, well-established data exchange, control of public authorities, and stability of the legal system. In other words, civic society is often forced to take over the functions of watchdog demanding accountability and transparency in government ${ }^{9}$. The American political scientist R. Inglehart stresses the importance of political culture and political trust, because "democracy is not attained simply by making institutional changes through elite-level maneuvering. Its survival depends also on the values and beliefs of ordinary citizens" $"$.

Western theoreticians of civil society A. Arato and J. L. Cohen define public control as an important part of state development, strengthening of its principles, institutions and regulations, which changes theoretical and methodological understanding of the interaction between man, society and the state. So, institute of control establishes the legal order and the principle of balance between the interests of society and government in a democratic regime ${ }^{11}$.

${ }^{7}$ Габермас Ю. Структурні перетворення у сфері відкритості: дослідження категорії «громадянське суспільство» / пер. $з$ нім. А. Онишко. Львів : Літопис, 2000. С. 68.

8 Даймонд Л. В напрямку демократичної консолідації. Глобальне відродження демократії / за ред. Л. Даймонда, М.Ф. Платтнера Львів; Ахілл, 2004. С. 292.

${ }^{9}$ Fukuyama F. What is Corruption? Against Corruption: a collection of essays : websites. URL: https://www.gov.uk/government/publications/against-corruption-a-collection-of-essays/ againstcorruption-a-collection-of-essays

${ }^{10}$ Инглхарт Р., Вельцель К. Модернизация, культурные изменения и демократия. Последовательность человеческого развития. М.: Новое издательство. 2011. С. 71.

${ }^{11}$ Коэн Д., Арато Э. Гражданское общество и политическая теория / пер. с англ. Мюрберг И. И. и др.. Москва : Весь мир, 2003. С. 34. 
The idea of control is central to the notion of democracy, since the ideal is one of giving kratos to the demos: giving maximal or at least significant control over government to the people. But it turns out that the notion of kratos or control is definable in various ways and that as the notion is differently understood, so the ideal of democracy is differently interpreted. Irish philosopher and political theorist, P. Pettit distinguishes between three different notions of popular control, arguing that only one is really suitable in democratic theory. Under the first conception of popular control, it means that the people have a causal influence on government; under the second, it implies that the people exercise intentional direction over government; and under the third (institutional control), it requires that the people enjoy an intermediate degree of power. That the only plausible candidate for interpreting the ideal is that of institutional control ${ }^{12}$.

As for the participation of citizens in managing state affairs, we should mention the research by S. R. Arnstein "A Ladder of Citizen Participation", which substantiates the difference between formal participation and having the real power. The lower levels of "manipulation" and "therapy" describe the nonparticipation forms that substitute for the effective forms of influence. According to scientist, the highest step of civic administration is citizen control that allows citizens to get a majority in political decision-making or even full extent of power ${ }^{13}$.

Thus, the priority importance of control consists in creating the conditions for the stability of the system, directing social and political processes to openness and transparency, implementing positive changes. Therefore, control functions are based on a set of rules and values that are generated in the community and imply assessing the activity of authorities and ensuring fundamental rights and freedoms of citizens.

\section{Regulatory and procedural characteristics of Public control}

Maturity and degree of formation of civic society depends on the level of "public authorities-public" dialogue, state of development of institutes of direct democracy and their legality under current legislation. In our research, the importance of addressing public control as an influence tool is confirmed by its multifunctional purpose, namely performing diagnostics of the state of cooperation between authorities and civic society; elaborating practical recommendations for further development of public sector; developing prognoses of public policy and possible transformations.

${ }^{12}$ Pettit P. 2008, Three Conceptions of Democratic Control / P. Pettit. An International Journal of Critical and Democratic Theory, 2008. Vol. 15, No. 1, pp. 46-55.

${ }_{13}$ Arnstein Sh. R. A Ladder of Citizen Participation / Sh. R. Arnstein. Journal of the American Institute of Planners, 1969. No 35 (4), pp. 216-224. 
In Ukraine, it is necessary to single out the laws that directly regulate forms of public control and also the legislative acts that create conditions for implementing technologies of feedback between authorities and the public. It should be noted that the public control system includes inspection, verification, monitoring, examination and supervision of public authorities, local governments and their officials. However, only public examination is defined by law as the feedback procedure at the regulatory level. According to the adopted Governmental Resolution of Ukraine "On approval of the Order on promoting the public examination of activity of the governmental authorities" № 976 of November 5, 2008, public examination is defined as a component of democratic governance that allows civil society institutes and public councils to perform the evaluation of activity of executive authorities, efficiency of making and executing decisions, the preparation of proposals for solving socially important issues for consideration by the executive authorities in their work ${ }^{14}$.

The Constitution of Ukraine (Art. 38) guarantees the right of citizens to participate in the administration of state affairs, in All-Ukrainian and local referendums, to freely elect and to be elected to bodies of state power and bodies of local self-government ${ }^{15}$. The mechanisms of public control include direct forms of will expression of the public (elections, referendums, public hearings, petitions, mass-meetings, etc.) and indirect activities through public organizations $^{16}$. Some researchers identify direct (investigative journalism, access to information, public discussions, jury trials, citizens' legislative initiative) and indirect (public councils, the institute of Ombudsperson, associations of related structures) forms of public control ${ }^{17}$. Of course, these forms are regulated by the respective constitutional norms (freedom of information, individual and collective petitions, the right to participate in administration of state affairs) and specialized legislation, such as the Laws of Ukraine "About Local Self-Government", “On Public Appeal”, “On Information", etc.

It should be pay attention to the specific forms of implementation of public control in the areas of improvement of settlements; environmental protection and others. In particular, such control is exercised by public

14 Про затвердження Порядку сприяння проведенню громадської експертизи діяльності органів виконавчої влади: Постанова Кабінету Міністрів України від 5 листопада 2008 р. № 976. Офіційний вісник України. 2008. № 86. С. 100.

${ }^{15}$ Конституція України : станом на 1 верес. 2016 р. / Верховна Рада України. Харків : Право, 2016. 82 с.

${ }^{16}$ Стрілець Ю. П. Види і форми контролю в місцевому самоврядуванні / Ю. П. Стрілець. Теорія та практика держсавного управління. 2011. Вип. 3. С. 353.

17 Пухкал О. Г. Громадський контроль як важливий чинник демократизації та ефективності державного управління / О. Г. Пухкал. Інвестиції: практика та досвід. 2010. № 14. C. 56. 
inspectors. This is largely due to the fact that the effectiveness of public control in these areas requires a certain level of skills.

The subject of public control in the mechanism of public administration has two meanings. The first is the total large number of subjects exercising public control in the public-legal sphere, the second is that every sphere of government is the subject of public control by several subjects, or even every citizen $^{18}$.

Different interpretations of forms and subjects are primarily due to the lack of uniform regulation of the institute of public control. For example, the draft Law of Ukraine “On Public Control” (№ 2737-1 of 13.05.2015) considers the following measures of public control: analytical and monitoring investigations; public examination; verification ${ }^{19}$. Draft law № 4697 of 14.04.2014 includes the following mechanisms of public control: access to information; creation and operation of public control organizations; participation of subjects of public control in the work of advisory bodies; individual and collective petitions; submission of requests by citizens; implementation of general and special procedures of public control, etc; the separate article highlights general (hearing reports on the results of work, public hearings, public monitoring) and special (public examination, verification and investigation) procedures ${ }^{20}$.

The last issue was initiated in 2018 by People's Deputy of Ukraine S. Kaplin. In particular, he prepared a draft law of Ukraine № 9013 of 07.08.2018 "On civil control over the activities of the authorities, their officials and services", which was submitted to the Committee on Legal Policy and Justice of the Verkhovna Rada of Ukraine. That is, instead of the concept of public, the term civic control is introduced, the content of which is civic control over the activity of the authorities, their officials. The draft law changes the conceptual approach to public control, its tasks, methods, mechanisms of implementation $^{21}$. All this does not contribute to the integrity and systematic character of public control.

However, let us note some progress in taking into account the interests of citizens during implementation of administrative decisions associated with the Law of Ukraine "On principles of prevention and combating corruption"

18 Кравчук В. Полісуб'єктність громадського контролю у механізмі державного управління/ В. Кравчук. National law journal: theory and practice. 2016. № 5 (21). C. 11-15.

19 Проект Закону України «Про громадський контроль» від 13.05.2015. № 2737-1 URL: http://w1.c1.rada.gov.ua/pls/zweb2/webproc4_1?pf3511=55101

${ }^{20}$ Проект Закону України «Про громадський контроль» від 14.04.2014 № 4697. URL: http://w1.c1.rada.gov.ua/pls/zweb2/webproc4_2?pf3516=4697\&skl=8

${ }^{21}$ Проект Закону України «Про громадянський контроль за діяльністю органів влади, їх посадових і службових осіб» від 07.08.2018 № 9013. URL: http://w1.c1.rada.gov.ua/ pls/zweb2/webproc4_1?pf3511=64506 
(2011, repealed in 2016), which provides for performing the public anticorruption examination, public discussion of legislation on giving preference to economic entities, etc. ${ }^{22}$. In addition, the conditions for performing public control are created by the Law of Ukraine "On Access to Public Information" (2011), the approval of the Concept of the draft Law of Ukraine "On Fundamentals of the State Communication Policy" (2010).

The new stage for normative regulation of public control started after the Revolution of Dignity, which demonstrated a higher level of civic selforganization and activity. The so-called "loud laws", namely "On Cleaning Power" (2014), "On the Open Use of Public Funds" (2015), "On Prevention of Corruption" (2015), embody the principles of "publicity, transparency and openness", lay the foundation for electronic declaring of officials, citizen participation in the budget process at the local level, which provides for the access to information on the budgeting process and its implementation, determination of efficient use of public funds.

Since 15 July 2016, it was announced the process of disclosure and initiated the launching of the electronic asset declarations system for those persons authorized to perform public functions, either at national or local level. National, regional and local authorities, as well as members of their families, are obliged to disclose their assets (real estate, monetary funds, cash, loans, etc.) and to declare possible conflicts of interest (job position, contracting services, participation in the civil council, etc.). This data remains open and available on a single state database of asset declarations ${ }^{23}$.

Also we would like to draw attention to the recently adopted document "National Strategy for Civil Society Development in Ukraine in 2016-2020 years" approved by the Decree of the President of Ukraine on February 26, 2016. This strategy clearly defined in Part 4 "Strategic Directions and Tasks", which include ensuring effective procedures for public participation in the formation and implementation of state, regional policies, addressing issues of local importance and implementation of public control over the activities of the body ${ }^{24}$.

At present, the development of concepts of e-democracy, e-government and e-citizen is a promising direction for the institutionalization of public control over the activities of the state. Within these concepts the possibility of

22 Про засади запобігання і протидії корупції : Закон України від 07.04.2011 № 3206VI. Голос Украӥни. 2011. № 107.

${ }^{23}$ Ukraine: Handbook on Transparency and Citizen Participation. Partnership for Good Governance. Council of Europe. 2017a URL:https://rm.coe.int/handbook-ukraine-eng/168078406c

${ }^{24}$ Національна стратегія сприяння розвитку громадянського суспільства в Україні на 2016 - 2020 рр., затверджена Указом Президента України № 68/2016 від 26.02.2016 p. URL : http://www.president.gov.ua/documents/682016-19805. 
using information technologies by citizens is considered not only to participate in the management of state affairs, but also in solving the whole spectrum of public tasks. Development of information and communication sphere resulted in creating Internet platforms "E-Data", "Prozorro", "Open Budget", The Unified State Open Data Portal which embody the principle of "availability as a lever to influence those in power".

Success stories like the implementation of the e-platform ProZorro boosted transparency and competition in public procurement. The major step was made towards open data in Ukraine with the adoption of the Law "About changes to some law on access to public information in form of open data", which introduced significant changes in other relevant legal acts. These changes obliged public authorities and local governments to publish and regularly update public information in the form of open data ${ }^{25}$. A new attitude to the "active citizen" as a real subject and participator of political process, a bearer of sovereignty and a source of political power should be formed in these conditions.

Scientific studies often include the following causes of poor development of public control: closed nature of bureaucratized public authorities, lack of appropriate social base, lack of knowledge about the basic tools of influence on authorities, inability to use them or simple indifference of citizens with conformist behavior.

However, "the most painful" task of political reform remains the combat against corruption and public control over openness and transparency of the political process. According to the report by Freedom House (2017), the inability of the authorities to defeat corruption in high places undermines the popularity of the government and affects the efficiency of reforms in various fields ${ }^{26}$. Based on the results of new 2016 Corruption Perceptions Index, Ukraine received 29 points out of 100, which is two points more than last year's index and does not indicate a major breakthrough in the fight against corruption. Experts find the major challenges to be weakness of the institutions intended to enforce the rule of law, excessive over-regulation of the economy and concentration of power in the hands of oligarchic clans. Thus, it is evident that the progress of recent years has been largely driven by the reforms that were launched in 2014. However, lack of political will remains one of the main factors in curbing anti-corruption progress ${ }^{27}$.

${ }^{25}$ Ukraine: Handbook on Transparency and Citizen Participation. Partnership for Good Governance. Council of Europe. 2017a URL:https://rm.coe.int/handbook-ukraine-eng/168078406c

${ }^{26}$ Report of Ukraine. Freedom in the World. 2017. URL: https://freedomhouse.org/ report/freedom-world/2017/ukraine

27 Індекс сприйняття корупції. Transparency International Ukraine. URL: https://ti-ukraine.org/research/indeks-koruptsiyi-cpi-2016/ 
Let us use the example of sociological data to determine the efficiency and effectiveness of public control mechanisms according to three levels of public participation: access to information (basic right that does not imply active dialogue), consultations (authorities invite the public to discussions concerning certain decisions) and active civic engagement through dialogue and partnerships (including mutual responsibility at all stages of policy-making, starting with putting issues on the agenda and up to adoption and implementation of decisions $)^{28}$.

Monitoring of Ukrainian central executive bodies' websites in 2015 (70 websites analyzed) implemented by the "Regional Press Development Institute" NGO proved that despite some improvements in the level of information transparency of the aforementioned authorities (54,74 in 2015 in comparison to 49,6 in 2013 and 48,3 in 2012), 45,26\% of information related to activities of central executive bodies still remains unavailable for users. However, despite the rather slow increase in the level of website openness, the number of sites with an openness rate of more than $60 \%$ is significantly increasing. The most closed, as in previous years, is information on spending of budget funds, publication of reports on tenders and use of state property ${ }^{29}$.

As for transparency of data, the research "Data of Ukrainian cities: open data in progress" held by the Civil Network OPORA states that there has been some progress in 2016, namely 16 cities were registered on a unified portal of open data; 10 cities publish their data in separate sections on their websites, even though often in unopened format. However, half of the surveyed cities have done no administrative action to open data ${ }^{30}$. Thus, it should be noted that at the very first level Ukraine has established the initial conditions for openness, but produced no systematic policy on the availability of information and work in open data format.

As for consultation, authorities have standardized mechanisms for consultations under the Governmental Resolution of Cabinet of Ministers of Ukraine "On public participation in the formulation and implementation of public policy" of November 3, 2010, and the amendments of 2015 introduced a procedure for electronic communications ${ }^{31}$. The study "The Practice of Using

${ }^{28}$ Public Participation in Europe: An International Perspective" (EIPP, 2009) URL: http://www.partizipation.at/fileadmin/media_data/Downloads/Zukunftsdiskurse-

Studien/pp_in_e_report_03_06.pdf

${ }_{29}$ Відкритість української влади. Результати моніторингу веб-сайтів центральних органів виконавчої влади України - 2015. Інститут розвитку регіональної преси. URL: https://irrp.org.ua/vidkrytist_ukrainskoi_vlady/

30 Дослідження стану розвитку даних в українських містах за 2016 рік «Дані міст України: open data in progress». 2016. URL: http://uacrisis.org/ua/51882-opendata

31 Про забезпечення участі громадськості у формуванні та реалізації державної політики : постанова Кабінету Міністрів України від 03.11.2010 № 996. Урядовий кур’єр. 2010. № 84 . 
E-Democracy Tools by Civic Organizations in Ukraine" (2016) reflects the practical side: $60.2 \%$ of public activists would like to use e-consultations, but only $19.4 \%$ of respondents used electronic consultations in their work. This difference between desired and obtained is due primarily to insufficient level of computer literacy or lack of appropriate tool that will allow deepening public control ${ }^{32}$.

At the third level, namely the active involvement in policy-making, there is lack of initiative and ignorance of citizens of Ukraine on forms of influence on public authorities. According to the research (2018) by the Ilko Kucheriv "Democratic Initiatives" Foundation in collaboration with the Razumkov Center shows that only $7 \%$ of citizens are involved in active civic activity - in fact, the same as in $2013-(8 \%)$. Similarly, membership of NGOs and associations has not increased compared to 2013: $87 \%$ did not belong to any of the organizations, associations or parties in 2018 and in $2013-85.5 \%{ }^{33}$.

Therefore, the question arises about the deepening of political socialization and education of ordinary citizens and civic society activists in order to effectively use direct forms of democracy, to build social capital and to improve the level of trust in the government.

\section{Potential possibilities to promote Public control}

One of the forms of ensuring accountability of public authorities is the activity of public organizations and movements. Ukrainian practice of influencing the public authorities is minor, but the positive changes are tracked in activation of the third sector, increase of trust in them and constant monitoring of the dynamics of implementation of reforms.

Western democracies distinguish three types of public control organizations: "observers/supervisors", classic "watchdogs" and "proactive monitors". "Observers" mainly record changes in key areas of society and work on general theories without aiming to promote the results of monitoring in real public policy. In addition to the supervisory functions, "watchdog" organizations actively work with information channels and promote their research products, making authorities use their groundwork to improve policy, to reassess the effectiveness of programs, etc. "Proactive monitors" are often ahead of authorities and institutions at the level of ideas and solutions, and, in fact, create methods of solving social problems before critical situations arise ${ }^{34}$.

32 Практика використання інструментів електронної демократії громадськими організаціями в Україні. Результати експертного опитування. ГО «Подільська агенція регіонального розвитку». 2016. С. 9-10.

33 Громадянське суспільство в Україні: виклики і завдання (2018). URL: https://dif.org.ua/article/gromadyanske-suspilstvo-vukraini-vikliki-i-zavdannya

${ }^{34}$ Стрілець Ю. Принцип підконтрольності в контексті концепції “good governance" / Ю. П. Стрілець. Актуальні проблеми державного управління. 2011. № 2. С. 322. 
At the same time, more than 350 public organizations (both with the status and without the status of a legal entity) are registered in Ukraine, in the names of which the word "control" is used in various phrases "public control", "popular control", "democratic control", "anti-corruption control". In most of them the main focus of the activity of the mentioned NGOs is human rights; methodological advisory and information; socio-political; educational and cultural-educational functions ${ }^{35}$.

There are several organizations that provide oversight of the public sector, but each one controls a certain range of activities or exercises regional influence. Thus, NGO OPORA specializes in monitoring the electoral process and monitoring of party programs; Committee of Voters of Ukraine promotes the deepening of democratic reforms in the country through independent public monitoring of the election and referendum processes and lobbying of respective legislative changes.

Let us single out the development of public control network "Act!" (Ternopil, Vinnytsia, Zaporizhia, Kramatorsk, Mariupol) which deals with advocacy, public and legal education, consolidation of local public sector. This kind of organizations abroad gather information about activities of authorities, organize public information week, acquaint with the means of public control, conduct trainings, seminars and monitoring. They not only perform control functions (watchdog), but also contribute to the political socialization of the population $^{36}$.

Due to some progress in the formation of public space, there is a particular increase of public requests regarding control over the budgeting process, implementation of reforms, process of cleaning power ("lustration"). In order to establish dialogue between activists and local authorities, the project "Local Public Control over Budget Spending" was launched with a goal to inform about the adopted anti-corruption legislation and the new bodies that will be tracking and combating corruption ${ }^{37}$.

Providing an unbiased assessment of the activities of authorities is ensured by analytical nongovernmental organizations (think tanks), which monitor the current state and identify problems of public administration bodies. They are developing very dynamic in recent years in Ukraine while increasing

35 Кравчук В. Полісуб'єктність громадського контролю у механізмі державного управління / В. Кравчук. National law journal: theory and practice. 2016. № 5 (21). С. 13.

${ }^{36}$ Березовський Д. О. Аналіз основних проблем при використанні моніторингу та контролю в системі державного управління / Д. О. Березовський. Інвестиції: практика та досвід. 2015. № 4. С. 154-156.

${ }^{37}$ Громадський контроль за використанням державних фінансів на місцевому рівні. Міжнародний центр перспективних досліджень. URL: http://icps.com.ua/nashi-proekty/ aktualni-proekty-mtspd/hromadskyy-kontrol-za-vykorystannyam-derzhavnykh-finansiv-namistsevomu-rivni/ 
their institutional, expert and analytical potential. An important advantage of think tanks is their relative remoteness, independence and detachment of state and bureaucratic interests. According to the analytical report "Independent think tanks and government: is there any progress in bilateral cooperation?", leaders of non-governmental think tanks in Ukraine are Ukrainian Centre for Economic and Political Studies named after Olexander Razumkov, Ilko Kucheriv "Democratic Initiatives" foundation, Centre of Policy and Legal Reform (CPLR), International Centre for Policy Studies (ICPS) and the Reanimation Package of Reforms (RPR). These organizations are trying to offer a picture of the real condition in a given area that requires change, and to present the innovative qualitative ideas, concepts and policies regarding reforms of the main areas of national life just as carefully and impartially ${ }^{38}$.

Increasing public control is also due to international programs aimed at creating a culture of cooperation, raising public awareness, improving service delivery. For example, the project "Dissemination of best practices of nongovernmental monitoring of administrative services" aims to improve feedback, to strengthen the capacity of NGOs and to form the basis for organizational change; the program "E-governance for government accountability and community participation" aims to introduce innovative models of citizen engagement; the project "Strengthening the capacity of civil society organizations in the regions of Ukraine to influence the state authorities and local self-government in order to accelerate reforms" is oriented towards providing activists with the necessary knowledge to influence the public authorities. International Renaissance Foundation, the Civil Society Development Foundation, Matra programme, DESPRO are particularly active in this direction and fund the development of a number of programs aimed at creating a civic society.

\section{CONCLUSIONS}

Thus, the development of control functions of civic society will help public authorities to determine the priorities of political course, to meet the principles of good governance, to reflect the real state of social and political attitudes and support of political decisions by population. Although public control is advisory by its nature, the detection of violations or inconsistency by public authorities leads to the formation of public opinion, public and political attitudes and trust in government institutions.

On the part of the citizens, we should note that public control is intended to create conditions for the prevention of corruption and irresponsibility of

${ }^{38}$ Kermach R., Sukharyna A. Independent think tanks and government: is there any progress in bilateral cooperation? Analytical report. URL: http://dif.org.ua/uploads/pdf/ 36483373158dd0b040e0aa2.11421606.pdf 
public authorities, to provide access to the necessary data, to establish instruments for continuous feedback, to improve the mechanisms of social partnership of the public, government and business.

That is why the implementation of these conditions should start from the local and regional level, where people have the opportunity for direct management in their communities in order to satisfy public demands and needs. It will result in "better united groups, susceptible to responsibility", which increases the social capital of the state.

\section{SUMMARY}

This research deals with the public control and citizen participation as the key tools in the development of good governance. Both help to create the conditions for citizens to understand and evaluate the decisions which the government is taking on their behalf. The regulatory support of the institution of public control in Ukraine is analyzed. The faults and gaps in the current legislation of Ukraine related to realization of public inspection are identified. Particular attention has been paid to the characteristics of the practice and projects of public control in Ukraine.

Summarize, that citizens must be allowed access to documents, proceedings and data pertaining to any legislation enacted by that government. It is through accountability that citizens are able to control their government and allow society to progress.

\section{REFERENCES}

1. Березовський Д. О. Аналіз основних проблем при використанні моніторингу та контролю в системі державного управління / Д. О. Березовський. Інвестииії: практика та досвід. 2015. № 4. С. 154-156.

2. Відкритість української влади. Результати моніторингу вебсайтів центральних органів виконавчої влади України - 2015. Інститут розвитку регіональної преси. URL: https://irrp.org.ua/vidkrytist_ukrainskoi_ vlady/

3. Габермас Ю. Структурні перетворення у сфері відкритості: дослідження категорії «громадянське суспільство» / пер. 3 нім. А. Онишко. Львів : Літопис, 2000. 318 с.

4. Громадський контроль за використанням державних фінансів на місцевому рівні. Міжнародний центр перспективних досліджень. URL: http://icps.com.ua/nashi-proekty/aktualni-proekty-mtspd/hromadskyy-kontrolza-vykorystannyam-derzhavnykh-finansiv-na-mistsevomu-rivni/

5. Громадянське суспільство в Україні: виклики і завдання (2018). URL: $\quad$ https://dif.org.ua/article/gromadyanske-suspilstvo-vukraini-vikliki-izavdannya 
6. Даймонд Л. В напрямку демократичної консолідації. Глобальне відродження демократії / за ред. Л. Даймонда, М.Ф. Платтнера Львів; Ахілл, 2004. С. 290-304.

7. Дослідження стану розвитку даних в українських містах за 2016 рік «Дані міст України: open data in progress». 2016. URL: http://uacrisis.org/ua/51882-opendata

8. Инглхарт Р., Вельцель К. Модернизация, культурные изменения и демократия. Последовательность человеческого развития. М.: Новое издательство. 2011.464 с.

9. Індекс сприйняття корупції. Transparency International Ukraine. URL: https://ti-ukraine.org/research/indeks-koruptsiyi-cpi-2016/

10. Конституція України : станом на 1 верес. 2016 р. / Верховна Рада України. Харків : Право, 2016. 82 с.

11. Корж К.М. Концептуалізація соціального контролю як технологічного засобу стримування соціальних відхилень соціологічних теоріях кінця XIX - початку XX століття/ К. М. Корж. Актуальні проблеми сочіології, психології, педагогіки. 2011. Вип. 13. С. 32-41.

12. Коэн Д., Арато Э. Гражданское общество и политическая теория / пер. с англ. Мюрберг И. И. и др.. Москва : Весь мир, 2003. 782 с.

13. Кравчук В. Полісуб'єктність громадського контролю у механізмі державного управління/ В. Кравчук. National law journal: theory and practice. 2016. № 5 (21). C. 11-15.

14. Національна стратегія сприяння розвитку громадянського суспільства в Україні на 2016 - 2020 рр., затверджена Указом Президента України № 68/2016 від 26.02.2016 p. URL: http://www.president.gov.ua/ documents/682016-19805.

15. Політична думка XX - початку XXI століть: методологічний та доктринальний підходи: у 2-х т./ за заг. ред. Н.М. Хоми. Львів: Новий Світ-2000, 2016. Т. 1. 516 с.

16. Поппер К. Відкрите суспільство та його вороги / пер. 3 анг. О. Коваленко: в 2 т. К. : Основи, 1994. Т. 1. 444 с.

17. Поцелуйко А. О. Образ держави в соціальному конструктивізмі та структурному функціоналізмі / А. О. Поцелуйко. Грані. 2015. № 7. C. $34-40$.

18. Практика використання інструментів електронної демократії громадськими організаціями в Україні. Результати експертного опитування. ГО «Подільська агенція регіонального розвитку». 2016. 49 с.

19. Про забезпечення участі громадськості у формуванні та реалізації державної політики : постанова Кабінету Міністрів України від 03.11.2010. № 996. Урядовий кур’єр. 2010. № 84. 
20. Про засади запобігання і протидії корупції : Закон України від 07.04.2011 № 3206-VI. Голос Украӥни. 2011. № 107.

21. Про затвердження Порядку сприяння проведенню громадської експертизи діяльності органів виконавчої влади: Постанова Кабінету Міністрів України від 5 листопада 2008 р. № 976. Офіційний вісник України. 2008. № 86. Ст. 100.

22. Проект Закону України «Про громадський контроль» від 13.05.2015. № 2737-1 URL: http://w1.c1.rada.gov.ua/pls/zweb2/webproc4_1? pf3511=55101

23. Проект Закону України «Про громадський контроль» від 14.04.2014 № 4697. URL: http://w1.c1.rada.gov.ua/pls/zweb2/webproc4_2? pf3516 $=4697 \&$ skl $=8$

24. Проект Закону України «Про громадянський контроль за діяльністю органів влади, їх посадових і службових осіб» від 07.08.2018 № 9013. URL: http://w1.c1.rada.gov.ua/pls/zweb2/webproc4_1?pf3511=64506

25. Пухкал О. Г. Громадський контроль як важливий чинник демократизації та ефективності державного управління / О. Г. Пухкал. Інвестииії: практика та досвід. 2010. № 14. С. 56-58.

26. Середа Т. Стратегічні орієнтири взаємодії органів державного управління з громадськістю у процесі реалізації конституційно-правової реформи / Т. М. Середа. Теорія та практика державного управління. 2018. Вип. 2. С. 81.

27. Стрілець Ю. П. Види і форми контролю в місцевому самоврядуванні / Ю. П. Стрілець. Теорія та практика державного управління. 2011. Вип. 3. С. 353-359.

28. Стрілець Ю. Принцип підконтрольності в контексті концепції "good governance" /Ю. П. Стрілець Актуальні проблеми державного управління. 2011. № 2. С. 319-325.

29. Туровский Р. Национализация и регионализация партийных систем: подходы к исследованию / Р. Туровский.Полития. 2016. № 1. C. $162-180$.

30. Arnstein Sh. R. A Ladder of Citizen Participation, Journal of the American Institute of Planners, 35 (4). (July 1969), pp. 216-224.

31. Fukuyama F. What is Corruption? Against Corruption: a collection of essays : websites. URL: https://www.gov.uk/government/publications/ against-corruption-a-collection-of-essays/against-corruption-a-collection-ofessays

32. Kermach R., Sukharyna A. Independent think tanks and government: is there any progress in bilateral cooperation?. Analytical report. URL:http://dif.org.ua/uploads/pdf/36483373158dd0b040e0aa2.11421606.pdf 
33. Pettit P. 2008, Three Conceptions of Democratic Control / P. Pettit. An International Journal of Critical and Democratic Theory, 2008. Vol. 15, No. 1, pp. 46-55.

34. Public Participation in Europe: An International Perspective" (EIPP, 2009) URL: http://www.partizipation.at/fileadmin/media_data/Downloads/ Zukunftsdiskurse-Studien/pp_in_e_report_03_06.pdf

35. Report of Ukraine. Freedom in the World. 2017. URL: https://freedomhouse.org/report/freedom-world/2017/ukraine

36. Ukraine: Handbook on Transparency and Citizen Participation. Partnership for Good Governance. Council of Europe. 2017a URL: https://rm.coe.int/handbook-ukraine-eng/168078406c

Information about the author:

Holubiak N. R.,

Candidate of Political Sciences (Ph.D),

Postdoctoral researcher,

Vasyl Stefanyk Precarpathian National University

57, Shevchenko str., Ivano-Frankivsk, 76000, Ukraine 